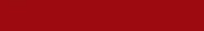

\title{
Masses, Leaders and Crisis. A Comparison between Four Theoretical Frameworks
}

\author{
Pietro Somaini, ${ }^{1}$ Marco Stucchi ${ }^{2}$ \\ ${ }^{1}$ University of Milan, Dipartimento di Filosofia Piero Martinetti, Italy \\ ${ }^{2}$ University of Rome Tor Vergata \& Roma Tre University, Dipartimento di Filosofia, Italy \\ marcogiovanni.stucchi@uniroma3.it
}

\begin{abstract}
In the 20th century the occurrence of revolutions, violent collective behaviours and dictatorships have shown the power of masses, raising many theoretical issues in sociology, philosophy and psychology. In this paper we will focus on four accounts in order to clarify the relation between a mass of human individuals and the role of a leader. These explanations are developed respectively by Weber, Le Bon, Frend and Girard. Even if our work is theoretical, we will briefly mention the French Revolution as solid example for a better understanding of mass-leader relation.
\end{abstract}

Keywords: Mass; Leader; Crisis; Max Weber; Gustave Le Bon; Sigmund Freud; René Girard; French Revolution.

DOI: 10.22618/TP.PJCV.20204.1.201010

The PJCV Journal is published by Trivent Publishing

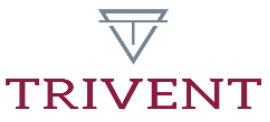

This is an Open Access article distributed in accordance with the Creative Commons Attribution Non Commercial (CC$B Y-N C$-ND 4.0) license, which permits others to copy or share the article, provided original work is properly cited and that this is not done for commercial purposes. Users may not remix, transform, or build upon the material and may not distribute the modified material (bttp:/ / creativecommons.org/ licenses/by-nc/4.0/) 


\title{
Masses, Leaders and Crisis. A Comparison between Four Theoretical Frameworks
}

\author{
Pietro Somaini, ${ }^{1}$ Marco Stucchi ${ }^{2}$ \\ ${ }^{1}$ University of Milan, Dipartimento di Filosofia Piero Martinetti, Italy \\ ${ }^{2}$ University of Rome Tor Vergata \& Roma Tre University, Dipartimento di Filosofia, Italy \\ marcogiovanni.stucchi@uniroma3.it
}

\begin{abstract}
In the 20th century the occurrence of revolutions, violent collective behaviours and dictatorships have shown the power of masses, raising many theoretical issues in sociology, philosophy and psychology. In this paper we will focus on four accounts in order to clarify the relation between a mass of human individuals and the role of a leader. These explanations are developed respectively by Weber, Le Bon, Freud and Girard. Even if our work is theoretical, we will briefly mention the French Revolution as solid example for a better understanding of mass-leader relation.
\end{abstract}

Keywords: Mass; Leader; Crisis; Max Weber; Gustave Le Bon; Sigmund Freud; René Girard; French Revolution.

\section{Introduction $^{1}$}

By looking at many of the social crises occurred in the last three centuries in Europe, one may observe two concurrent phenomena: a significant number of individuals gathering in a mass and, at the same time, the ascendency of a powerful leader. The most famous examples are Lenin, Mussolini and Hitler, for the dictatorships established after the First World War, or Robespierre and Napoleon in the context of the French Revolution.

Our core question is: what role does a leader play in the social process that brings masses together? In order to address this question, we must clarify not only whether the leader is a solver or an element of exasperation of social crisis, but also whether his ${ }^{2}$ causal powers are due to objective personal features and abilities. Moreover, we will clarify whether the role of the leader is active or passive.

The issues at stake are plainly theoretical. Our paper does not examine a historical leader nor a specific historical crisis, but rather the concepts of the leaders, masses and crisis. Furthermore, our inquiry is not conducted on a moral level: we will not discuss whether groups' and leaders' actions are in line with any moral law. Our analysis is intended to go beyond any historical consideration and the moral judgments.

Because all four accounts examined are theoretical, we will not follow their chronological order, as we are not interested in a history of ideas, but rather we want to explore the conceptual evolution of the problem. The first author taken into consideration will be Max

\footnotetext{
${ }^{1}$ This paper is the product of a collective work by the two authors. However, the ultimate responsibility for the introduction, sections II and V is on Pietro Somaini, while the ultimate responsibility for sections $\mathrm{IV}, \mathrm{V}$ and the conclusion is on Marco Stucchi.

${ }^{2}$ In order to avoid confusion, we will always use the male pronoun to refer to leader, as our four authors do.
} 
Weber and his work Economy and Society (1922). Although Weber does not make use of terms like "leader" and "mass," their relation can be clarified by notions of "charisma" and "followers." Then we will focus on Gustave Le Bon's The Crowd: A Study of the Popular Mind (1895). Next, we will discuss Sigmund Freud's theory as it was depicted mainly in Group Psychology and the Analysis of the Ego (1921). Finally, we will consider Girard's mimetic theory. Our aim consists in showing that this last account can include valid intuitions contained in the three previous works, whilst shedding light on the issues they leave unresolved. We will show how Girard's theory may provide an accurate explanation of leadership, whereas in other theoretical frameworks the same notion appears as an element of singularity, in the sense of an inexplicable primitive element.

In the first instance, we would like to clarify the concept of crisis for its ambiguous meaning. On one hand this term can be applied to describe the clash between a mass and external social institutions; on the other it can equally refer to the disruption occurring within the social order of a mass. Regarding this ambiguity, whereas Weber studies the opposition between a mass of followers and an existing authority, Freud is more interested in the internal connections established within a group of people instead. Therefore Freud, as well as Girard, conceives crisis as a loss of social bonds between members of a mass and does not take into account the role of external institutions.

Even if our paper is theoretical, we will briefly mention historical facts. They will provide substantial examples that may prove useful for understanding the topics presented and verifying their applicability. Historical facts selected will concern the French Revolution, given that on the basis of Hegel's remarks this event has been recognized as one of the most important moments in European history. In The Philosophy of History, Hegel describes the severe social crisis that caused the Revolution:

The political condition of France at that time presents nothing but a confused mass of privileges altogether contravening Thought and Reason — an utterly irrational state of things, and one with which the greatest corruption of morals, of Spirit was associated - an empire characterized by Destitution of Right, and which, when its real state begins to be recognized, becomes shameless destitution of Right. The fearfully heavy burdens that pressed upon the people, the embarrassment of the government to procure for the Court the means of supporting luxury and extravagance, gave the first impulse to discontent. The new Spirit began to agitate men's minds: oppression drove men to investigation. [...] The entire political system appeared one mass of injustice. ${ }^{3}$

It was not an ordinary crisis with ordinary effects, but the very paroxysm of the crisis of the modern age. In fact, many history books report that the modern age ended in 1789, with the storming of the Bastille. In this context some individuals, in particular Robespierre and Napoleon, became leaders. These two individuals, in some respects, were curiously similar. At the time of their success, they were the solution to the crisis, the saviors of the French people, and yet not long after they were identified as responsible for all the problems of the country. We should note that this is the point of view of the mass and of some history books. ${ }^{4}$ Thanks to a better comprehension of mass-leader relation, we will be able to understand these

\footnotetext{
${ }^{3}$ Georg Wilhelm Friedrich Hegel, The Philosophy of History (Kitchener, Ontario: Batoche Books, 2001), 466.

4 'Within days the legend of Robespierre's cruel appetite for violent retribution was to be invented as a central truth of the Revolution. It remains uncontested in most of the biographies of Robespierre and general histories of the French Revolution". P. McPhee, Robespierre and violence, in Experiencing the French Revolution, ed. D. Andress (Oxford: Voltaire Foundation, 2013), 69.
} 
judgments and to define the real role of these two individuals in the social dynamics they faced.

\section{Weber: the Relation between Charisma and Followers}

Max Weber's posthumous work Economy and Society (1922) introduced to sociological studies the notion of charisma. It is his elaboration of a religious term - deriving from the Greek charis, "grace", and meaning the grace granted by the divine - and becomes a sociological one. The issue is no longer the relation between an individual and God, but rather the relation between a leader and his followers. Weber presents charisma as one of three types of authority, ${ }^{5}$ expecting that followers are subjected to this charismatic authority, they are compelled to obey it. The definition of charismatic authority in Economy and Society is:

resting on devotion to the exceptional sanctity, heroism or exemplary character of an individual person, and of the normative patterns or order revealed or ordained by him. ${ }^{6}$

The charismatic leader appears as an exceptionally powerful character, a hero. Is he then a social crisis solver? According to Weber people follow the leader by virtue of his heroism, turning themselves into a mass, a community (Gemeinde), uniting around him. Since the moment a charismatic figure finds his community to lead, he henceforth sees his authority confirmed and validated. One can then say that authority is therefore sustained by a mass of followers, which through their acknowledgement of a new leading person mark the beginning of a renewed order that ends a period of crisis.

Moreover, Weber shows that charisma is not just one of the three types of authority: it is the one which opposes the other two. It is "a revolutionary force" that "repudiates the past."7 Specifically, "in traditional periods, charisma is the great revolutionary force." 8 Followers are a mass which at first instance does not constitute new authority, as they must destroy the existing one first. In this sense can charisma be considered an element of exasperation of social crisis rather than a possible solution?

We can argue with Weber that the charismatic leader is an element that may equally reduce and intensify a crisis. To support this counterintuitive thesis, we can observe an interesting dynamic during the French Revolution, emphasized by Hegel in The Pbilosophy of History:

Robespierre set up the principle of Virtue as supreme, and it may be said that with this man Virtue was an earnest matter. Virtue and Terror are the order of the day; for Subjective Virtue, whose sway is based on disposition only, brings with it the most fearful tyranny. ${ }^{9}$

The leader initially bolsters an ideal of Virtue as solution to the crisis, but over the long term this endorsement might cause an exacerbation of the crisis itself. So, which effect is caused by a leader's objective features and actions? It seems absurd that virtue may cause an escalation of violence such as the French people witnessed during "The Terror." ${ }^{10}$ For, even

\footnotetext{
5 The other two are rational and traditional authorities.

${ }^{6}$ Max Weber, Economy and society: an Outline of Interpretative Sociology (Los Angeles, California: University of California Press, 2001), 215.

7 Ibid., 244.

8 Ibid., 245.

${ }^{9}$ Georg Wilhelm Friedrich Hegel, The Philosophy of History, 470.

10 In his speech, delivered on 5 February 1794, Robespierre claimed: "virtue, without which terror is disastrous; terror, without which virtue is powerless". See P.R. Hanson, Contesting the French Revolution (West Sussex: Wiley-Blackwell, 2009), 125.
} 
though there are different explanations for this eventuality; sometimes the leader is not virtuous enough, or the virtues he pursues are not the right ones, or, perhaps, the problem is not virtue at all.

According to Weber himself, the long-term solution to avoid crisis is discipline, not a charismatic individual and his personal features. Weber focuses on the conduct of war, even though it is valid for any context in which violence must be contained. During social crisis the enemy is usually not identified externally, but, as we have said, it is found in the dominant authority and its institutions, which must be destroyed, often leading on the brink of civil war. Without discipline any victory is momentary: this explains the oscillation in which crisis and violence is reduced and intensified. Weber observes that charismatic attitude, like the one shown by Napoleon in France, may create "a strict disciplinary organization," 11 and this is what solves the crisis, not the leader himself. This new order, once created, makes charismatic individual unnecessary. Precisely because the discipline involves everybody, it is the best solution for keeping the mass together. Then which role does the leader's heroism really play? Its real efficacy appears unfathomable.

This is an unsolved problem in Economy and Society. If we focus on a charismatic figure, we note that even its objectivity is not so clear, as the author is ambiguous in this regard. We find the term "heroism" in his definition, which is supposed to be an objective description given by a sociologist; but Weber himself denies its objectivity:

How the quality in question would be ultimately judged from any ethical, aesthetic, or other such point of view is naturally entirely indifferent for purposes of definition. What is alone important is how the individual is actually regarded by those subjects to charismatic authority, by his "followers" or "disciples." 12

Therefore, a charismatic figure is not really a hero or an exceptional individual; this is what the followers are drawn to think. The difference is fundamental: the follower is not a sociologist. A sociologist should know that the charismatic figure may be different than what a follower thinks or perceives, and he must investigate to find out what it really is. Then why is Weber's definition of charisma identical to the follower's thought?

In some of his considerations, in fact, Weber seems to suggest that people are drawn towards the objective features of a leader, whereas in other passages he seems to sustain that it is the endorsement of a crowd that bestows certain attributes on a chosen chief. Whether this effect seemed caused by charismatic leader's actions, now he seems much more passive: the others, united in a mass around him, think he is exceptional, so he becomes charismatic. In fact when Weber observes how a leader is chosen by others, he notes that it is not a subjection in accordance with objective data, but it is an alleged "revelation" of objective data in accordance with subjection:

It is not a matter of free selection, but of one which is strictly bound to objective duty. It is not to be determined merely by majority vote, but is a question of arriving at the correct designation, the designation of the right person who is truly endowed with charisma. It is quite possible that the minority and not the majority should be right in such a case. Unanimity is often required. It is obligatory to acknowledge a mistake and persistence in error is

\footnotetext{
11 Max Weber, Economy and Society: an Outline of Interpretative Sociology (Los Angeles, California: University of California Press, 2001), 1149.

12 Ibid., 241-2.
} 
a serious offence. Making a wrong choice is a genuine wrong requiring expiation. Originally it was a magical offence. ${ }^{13}$

We observe that there is not an objective charismatic quality "before" (from a logical point of view), which explains the next subjection. That is what the follower thinks, precisely because there is the subjection from the beginning. The alleged charismatic quality arises out of the subjection ("after" from the logical point of view).

The real cause of subjection is not investigated by the German sociologist. In fact, if all these considerations suggest that the charismatic individual is not really a hero, an exceptional one, many other points, like the important definition, disregard those.

Weber also claims that charismatic leader "is self-determined and sets its own limits," 14 denying the essential relation with his followers. But according with other considerations, it is the mass of followers who defines and determines the charismatic nature of one individual. Naturally followers are not aware of this: they believe they have beheld a revelation. They believe in charismatic leader's self-determination. But, again, a sociologist should not think like a follower: he should not believe in charismatic leader, as he should rather try to explore this belief.

Another problematic description is the one about the relation with economy. Weber argues that a charismatic individual "is a typical anti-economic force." 15 Who holds the charisma, according to Weber, must not be interested in profit, because it is not in opposition with only the other two authorities, but also with the economic system. Even when he makes a profit, he "can only tolerate [it] with an attitude of complete emotional indifference." 16

This point is fundamental: why does the German sociologist attempt to describe the inner emotions of an individual? If one shows himself indifferent, it does not mean that he is really indifferent after all. It is not a phenomenon which can be observed from the outside. Which sociological method can be used to prove this consideration?

While Weber describes the charisma-followers relation, he notes a very essential element: this relation involves the followers' interiority. Followers experience a metanoia, that is a radical change in the way they think. The absolute devotion to the heroism cast by a charismatic leader does not need to be grounded on realistic events or actions, insofar as it springs from the change of mind installed by the metanoia. This process produces a stark connection between a leader and his followers, inasmuch as the latter believe to know intimately the interiority of their chief and are subjected to it.

Therefore, we can argue that Weber, describing charismatic individual's interiority, is not in the position of a sociologist, as he identifies with a follower. He believes he knows charisma like a follower does. If it is true for these descriptions, we can assume that it is true for the definition, too. Also, when the heroism is presented as an objective quality, which defines the charismatic figure, Weber identifies with a follower. It is the follower who believes in charismatic leader's heroism, in his exceptional nature.

The proof is that in Economy and Society the problem of the efficacy of charisma remains unresolved. Weber does not explain why the followers become a mass around this individual and he does not clarify the means through which a charismatic authority arises. Also, he does not explain why this authority may eventually collapse either. He observes that charismatic figure may be not the solution of a social crisis, but an element of exasperation, until the holder of leadership is appointed as the real cause of every turmoil. But the German

\footnotetext{
13 Ibid., 247.

14 Ibid., 1112.

15 Ibid., 245.

16 Idem.
} 
sociologist does not explain how this actually happens. He recognizes the arbitrary nature of positive or negative judgements, without showing how things really are and how those judgements arise however. When Weber refuses followers' accusations, he does not offer a reflection on objective criteria, on basis of which a sociologist can refuse or accept these accusations.

For this reason a ruler such as the Chinese emperor, whose power stills contains — in theory — important charismatic vestiges, may publicly accuse himself of his sins and insufficiencies, if his administration fails to banish the distress of the ruled, whether it is caused by floods or unsuccessful wars; we have witnessed this in China even during last decades. If this penitence does not propitiate the gods, the ruler faces deposition and death, often enough as an expiatory sacrifice. ${ }^{17}$

It is not a moral problem but theoretical: the sociologist does not refuse the accusation for disapproving its morality, but for he does not recognize in the charismatic individual the cause of disruption. In the last case it is easy to see that the charismatic emperor is just a scapegoat, as accusations are clearly due to superstition. A flood cannot be caused by an individual: the charismatic one is clearly passive in this situation, none of his action explains his failure. If the sociologist is not superstitious, he does not run the risk of identifying with the follower, who has become the accuser.

But without objective criteria we can hardly understand whether a charismatic individual is a scapegoat or not, as the alleged accusations are not always due to superstition, as in the case of the Chinese emperor. It appears very complicated to determine whether Robespierre was the real culprit or just a scapegoat in the context of the French Revolution. We know that while he was an authority, a charismatic authority, many people were guillotined. So, was he the real culprit and his failure the result of his actions? Or was he not? Because, we also know that he was guillotined abruptly and without trial: is this enough for him to be considered a passive scapegoat?

As well, Hegel argues that the French leader "set up the principle of Virtue as supreme," but while doing so he established a "Reign of Terror." In his opinion, Robespierre seems to have played an active role in both his rise and his fall, but the German philosopher does not study the charisma-followers relation.

Instead in Economy and Society, in which the issue of this relation is introduced, the problem is not that Weber does not offer a reflection on Robespierre's case, the problem is that the German sociologist does not offer the tools to resolve it.

In conclusion, we can argue that what we should retain in Weber's definition is not the heroism of the charisma, but his "sacred" nature. In this way we are able to point out that his exceptionality depends on the followers' belief.

\section{Le Bon: the Role of Prestige}

The Crowd: A Study of the Popular Mind (1895) by Gustave Le Bon is considered a pioneering classic in the field of mass psychology. We are going now to show and discuss Le Bon's insights on mass-leader relation and on social crisis in this work.

In spite of an overall negative judgment on crowds $^{18}$ (foules) Le Bon is ambiguous in his characterization of the relation between the emergence of crowd and social crisis. As we wrote in the introduction there are two meanings of crisis and Le Bon does not clearly distinguish

\footnotetext{
17 Ibid., 1114-1115.

18 In order to simplify our paper, we will not line a difference between crowd and mass.
} 
among them. On one side Le Bon has got a moralistic negative judgement on crowds for their power in bringing upheavals, ${ }^{19}$ that is a structural crisis of pre-existing social system; on the other side Le Bon talks about a mental unity of crowds. ${ }^{20}$ In this second sense a crowd is able to form a unit, that is a system. Mass then, according to Le Bon, can be the causes of a crisis in relation to pre-existing social institutions, but for what concerns the mass an object in itself, a mass is a system. In the next pages we will focus on the second sense of this crisissystem opposition, ${ }^{21}$ because it fits better with the analysis of Freud and Girard. In this sense a system, as opposite of crisis, means the mass considered in itself, as a unit; and crisis, as opposite of system, means the mass' disruption.

Let us consider now what it takes, according to Le Bon, for a mass to be a unit, a system. Le Bon believes crowds are not just a mere mereological sum of single individuals, their existence, in fact, requires some "excitant." 22

Among the various factors that would be able to turn a sum of individuals into a mass, Le Bon mentions:

[...] the disappearance of the conscious personality, the predominance of the unconscious personality, the turning of feelings and ideas in an identical direction by means of suggestion and contagion, tendency to immediately transform the suggested idea into acts $[\ldots] .^{23}$

First, we have to point out the preponderance of the unconscious in the mental life - and consequently in the behaviour - of the single individual in a crowd. Moreover, two relevant terms occur: "suggestion" and "contagion." Despite the important role of these two concepts in Le Bon's characterization of mass psychology, the author shows an embarrassing vagueness on their definition and he says explicitly that their real functioning is unknown. ${ }^{24}$ If on one hand contagion should explain how an act, a sentiment or an idea can spread quickly in a mass ${ }^{25}$; suggestibility instead refers to that state of high receptivity experienced by an individual in a mass, which is to indicate a condition of passivity that runs through a crowd. ${ }^{26}$ A mass then can be described as a group of individuals whose personalities are cancelled, or strongly diminished, and in which an impulse - it can be an action, a sentiment or an opinion - can be easily embraced and pursued impetuously, by virtue of suggestibility, and can spread easily through the members of a group by virtue of contagion. We have to note that the appearance of these factors determines a gap between individual psychology and social psychology, for in the second field there are concepts and phenomena that do not appear in the first one. In Freud's account, as we shall see, the critique of this saltus plays a fundamental role.

The central question for our inquiry is: where does the "suggestive" impulse comes from? It is noteworthy that Le Bon writes that the psychological state of an individual in a crowd is similar to the mental state of a subject under hypnosis. ${ }^{27} \mathrm{~A}$ hypnotized individual is tidy bound to unconscious activities "which the hypnotizer directs at will." 28 It seems then that suggestion requires the presence of a hypnotizer-like figure: something or someone that can determine

\footnotetext{
${ }^{19}$ Gustave Le Bon, The Crowd: a Study of the Popular Mind (New York: Cosimo Classics, 2006), ix.

${ }^{20}$ Ibid., 1.

${ }^{21}$ Even if Le Bon is more concerned, in many points of his work, with the first sense.

${ }^{22}$ English translation uses the more general "predisposing causes." Ibid., 2.

${ }^{23}$ Ibid., 8.

${ }^{24}$ Ibid., 7.

${ }^{25}$ Ibid., 6, 14.

26 Ibid., 7-8.

${ }^{27}$ Ibid., 7.

${ }^{28}$ Idem.
} 
the direction of mass mental impulses, functioning as a coordinator. In a mass this role pertains to a leader.

Chapter Three of the second book of The Crowd is dedicated to the leader. Again, as we have already seen in Weber, there are some fluctuations and uncertainties. However, we will make an attempt at presenting Le Bon's consideration. In the first page of this chapter ${ }^{29}$ a double movement takes shape. On one hand Le Bon investigates who can use the impulses of a crowd, assuming - at least it seems so - a sort of active role of the leader who is able to handle the mass impulses. On the other hand, the author, supposing the existence of a proper animal herd instinct, writes that individuals gathered in a certain numbers will instinctively look for the authority of a leader. Despite some fluctuations we must point out that in both cases Le Bon postulates of a chief, a leader, who, in some way, is already given. The will of this leader, due to its autonomy, has a certain logical antecedence in respect to the mass and plays a crucial role in the process that defines the "mental unity" of the crowd. In fact, the leader's will constitutes the core around which individual impulses in a mass take shape and are oriented.

Is it then, according to Le Bon, the will of the leader that constitutes the primum, the "primary spark" that determines and explains the behaviour of a mass? Not exactly, as we can once again read from Le Bon's words:

The leader has most often started as one of the led. He has himself been hypnotised by the idea, whose apostle he has since become. ${ }^{30}$

It is like the leader is possessed by an idea. Words and images used by the French thinker - hypnosis, possession, faith - seem to point towards a certain passivity in respect to something external. At this point we can raise two questions: how can a leader maintain an independent will; and, more importantly, why does every person in a mass select a particular will to identify with? Le Bon has got an interesting insight for the first question (even if he does not elaborate it):

They [leaders] are especially recruited from the ranks of those morbidly nervous, excitable, half-deranged persons who are bordering on madness. ${ }^{31}$

That is how leaders can exhibit a will that "stands out." They manage to do this thanks to a condition of mental (and probably social) marginality. They pursue an idea, an opinion, or an impulse with total devotion, so they result immune from that suggestibility and contagion which dominate the crowd. This is the reason why their will can work as a first impulse that determines the masses' mental unity. But this does not suffice to explain why a particular outstanding will is "chosen" by the mass. Le Bon believes that the leader has to possess another quality, without which he cannot carry the mass. Here "prestige" 32 makes its appearance.

Prestige for Le Bon - who defines it as a mysterious force ${ }^{33}$ — can be the predicate of a person or an idea. Since we are exploring the concept of leaders, we will focus on individual prestige. The author indicates some means to acquire prestige. ${ }^{34}$ Among these means there is

\footnotetext{
29 Ibid., 72.

30 Idem.

31 Ibid., 73. Here Le Bon makes the example of Robespierre: "An example in point is Robespierre, hypnotised by the philosophical ideas of Rousseau, and employing the methods of the Inquisition to propagate them." Idem.

32 Ibid., 77.

33 Ibid., 81.

34 Ibid., 77-80.
} 
imitation, ${ }^{35}$ which however - Le Bon repeats it different times — is just an effect of contagion: when an act or a person is imitated, namely when it is endowed with a contagious effect, then prestige is acquired.

Le Bon defines "prestige" as "a sort of domination exercised on our mind by an individual, a work, or an idea," 36 something that "may involve such sentiments as admiration and fear," 37 a domination that "entirely paralyses our critical faculty, and fills our soul with astonishment and respect." 38 It does emerge here as an ambivalent nature of Le Bon's prestige: it can frighten, intimidate, but also astonish and generate admiration.

For our inquiry we have to face the same relevant question we have met in Weber when he referred to heroism: where does prestige come from? We can figure out two main options: it can be a group of people who attribute prestige to an individual (bringing out prestige's existence), or prestige springs from a sort of inner source of prestigious individual (and people just recognize it). ${ }^{39}$

It seems clear that Le Bon would incline unequivocally towards the second option. In fact he writes that an efficient means for carrying a crowd is contagion, that is the imitation of a leader's actions and ideas, ${ }^{40}$ but he explicits that the sample of leader is doomed to sterility if he does not already possess prestige. ${ }^{41}$ We quote here a passage that makes very clear the antecedence of a leader's prestige in respect of his relation with the mass:

The great leaders of crowds, such as Buddha, Jesus, Mahomet, Joan of Arc, and Napoleon, have possessed this form of prestige in a high degree, and to this endowment is more particularly due the position they attained [...]. The great personages I have just cited were in possession of their power of fascination long before they became illustrious and would never have become so without it. It is evident, for instance, that Napoleon at the zenith of his glory enjoyed an immense prestige by the mere fact of his power, but he already endowed in part with this prestige when he was without power and completely unknown. ${ }^{42}$

We can sum up now Le Bon's argumentation following the inversal path, not from mass to leader but from leader to mass. The leader has two essential features: a strong dedication to an idea (and a consequent will determined by such idea) and prestige. By means of these two features, the leader imposes himself to the mass, which is naturally drawn towards a leading figure as moved by a so-called herd instinct, namely the instinct of submission to a leader's will. In this way, thanks to the leader, a disorganized and uneven mass turns into a compact and shaped mass. In particular, unconscious and disorganized impulses find an unifying principle, the leader's will. Because of suggestibility the mass accepts this external force, which, by contagion, spreads very quickly among all the members, turning into a "dogma."

We would like to point out again how Le Bon's intuition somehow refers to a double movement. On one hand there is a movement that starts from the mass, which instinctively searches for a leader (in this respect the leader is passive); and on the other hand there is a movement that sparks from the leader, who is able to play an active role thanks to his prestige.

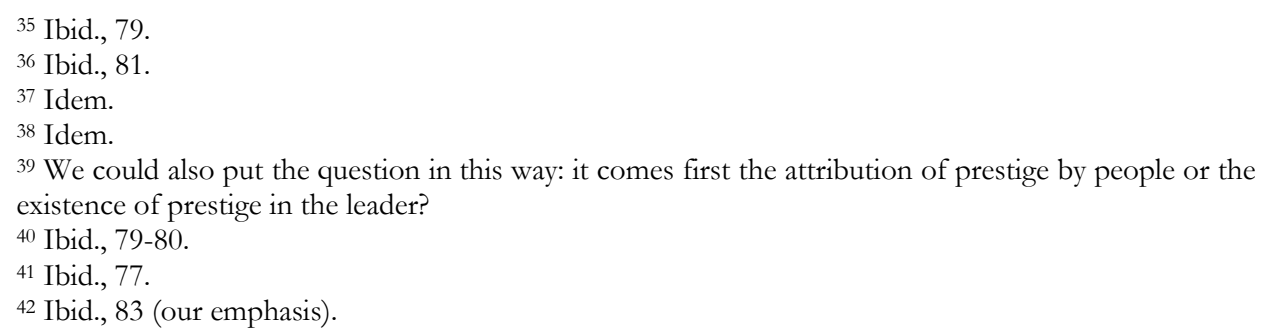


Prestige and herd instinct are not precisely defined and explained by the French author, but we can infer from his words that these two elements need to coexist so that a mass can unify and persist over time.

The leader then, according to Le Bon, gives cohesion to the mass, ${ }^{43}$ and by exhibiting a will to follow, a faith — as Le Bon calls it —, he multiplies the mass' power. The leader's influence on the destructive power of a mass can vary. Depending on his temperament ${ }^{44}$ and other side conditions a mass might as well be protagonist of carnage or of heroic deeds and self-abnegation. ${ }^{45}$ Leader's capacity of giving cohesion to a mass can be described as a capacity of giving shape to the impulses of the individuals in a certain group by pointing out a common direction to them. If, on one hand this usually creates an ordinate system, a cohesive mass, on the other hand it might lead to direct violent acts against an external object.

We conclude then that Le Bon's leader plays his role partially by virtue of a property, prestige, that is in its essence independent from mass opinions, behaviours or attributions. A mass, of course, can increase the prestige of an individual, but it cannot determine it. This singularity of the leader in Le Bon's account is confirmed by the fact that Le Bon believes that this ambivalence is due to some leader's personal traits. We have also shown that in Le Bon's analysis of mass behaviour there is a significant amount of concepts that remain undefined and unexplained. In the next section we will see how Freud takes up the challenge and makes some important steps forward in the clarification of mass-leader relation and in mass psychology in general.

\section{Freud: the Father and Identification}

Le Bon's book became "deservedly famous" 46 ; this is what Freud says about The Crowd: a Study of the Popular Mind The Crowd in Group Psychology and the Analysis of the Ego (1921). The second chapter of Freud's text is dedicated to the description of masses proposed by the French author. Despite the credits recognized to Le Bon's work, Freud points out, with the usual precision, some relevant flaws. Basically Freud accuses Le Bon of supposing, in his description of mass psychology, an overly high number of primitive elements, namely not reducible concepts, or concepts that Le Bon does not make sufficent effort to reduce. Moreover, by supposing such a variety of ad hoc concepts, Le Bon draws a deep gap between individual psychology and social psychology (or mass psychology). One of the main attempts of Freud's work is to show that this rigid dichotomy does not subsist. ${ }^{47}$

In order to explain what determines the cohesion of a mass, without which a mass would not be considered as such, Freud will not use categories or concepts which would not be applied to a single individual first. Indeed according to Freud "individual psychology [...] is at the same time social psychology as well." ${ }^{4}$ We saw Le Bon indicating three preliminary conditions for the formation of a cohesive mass: predominance of unconscious impulses in individuals, suggestibility and contagion. In his analysis Freud maintains the predominance of unconscious activities, but he intends to explain the other elements.

Obviously Freud's account is to be read within the framework of psychoanalytic studies, and here, due to the spatial limits of this paper, we will have to take for granted some of his

\footnotetext{
${ }^{43}$ Ibid., 75 .

${ }^{44}$ Idem.

${ }^{45}$ Ibid., 22.

46 Sigmund Freud, Group Psychology and the Analysis of the Ego, in The Standard Edition of the Complete Psychological Works of Sigmund Freud. Vol. XV III (1920-1922), ed. J. Strachey (London: The Hogart Press, 1957), 72.

${ }^{47}$ Ibid., 69.

48 Idem.
} 
most renowned concepts. In order to explain the phenomena described by Le Bon, Freud discharges the vague concepts advanced by the French author and applies the concept of libido. As we know libido in psychoanalysis is the energy of pulsions "which have to do with all that may be comprised under the word 'love'," 49 and it creates positive bonds between individuals. The second important element of Freud's account is "identification," defined as the desire to be like somebody else. Freud has claimed that the first and most relevant identification is the child's identification toward his father: "A little boy will exhibit a special interest in his father; he would like to grow like him and be like him, and take his place in everywhere." 50

The interpretation of the relation between libido and identification is one of the most relevant issues in Freud's thought. In the vast majority of Freud's works libido, defined as object-related love, precedes identification, the desire to be like another person. However, in Group Psychology Freud clearly states that "identification" is the earliest emotional tie with another person..$^{51}$ We cannot study this complex issue in detail, ${ }^{52}$ even if it matters to some extent for our inquiry. Since we are referring mainly to Freud's Group Psychology we will accept identification's priority in respect to libido.

We note that, according to Freud, identification appears ambivalent from the beginning: "it can turn into an expression of tenderness as easily as into a wish for someone's removal." 53 It is worthy to underline the proper "place" of this ambivalence. We remember that Le Bon attributes ambivalence to the prestige, for it can induce sentiments of fear or sentiments of admiration, and the prestige is embodied by the leader. Freud believes instead that ambivalence is in the identification of the child with his father. Ambivalence then is due to a psychic activity of an individual, not, as in Le Bon, in an objective quality that remains external to the individual somehow (the prestigious person or the prestigious idea)..$^{54}$

According to psychoanalysis the identification with the father, the investment of libido, and the relation of these two forces, has the power to shape the mind and behaviour of those who are subjected to it for the rest of their lives. It is important to note that identification with the father and the objective love for the mother, according to Freud, are fundamental elements in a "normal" development. Then there is a common mental structure for all the individuals raised in an ordinary familiar context, ${ }^{55}$ namely the great majority of individuals in a society. Psychoanalytic account of mass behaviour considers this a given fact. Individuals - here we can note the continuity of Freud's approach as opposed to the discontinuity of Le Bon's one - already share certain impulse before they gather in a mass. In particular they share identification with a father (or substitutes of him).

This communality of impulses, writes Freud, determines a second identification, that can be defined as an "horizontal" identification, that is the reciprocal identification among members of a mass. ${ }^{56}$ Individuals in a mass can exhibit affective bonds as long as they suppose a vertical identification with one individual out of the mass. This passage deserves a clarification. Just as "primary" identification — that is the identification with a father figure

\footnotetext{
49 Ibid., 90.

50 Idem.

51 Ibid., 105.

52 For an analysis on this point, see Mikkel Borch-Jacobsen, The Freudian Subject, ed. by C. Porter (Stanford: Stanford University Press, 1988), 153-194.

53 Idem.

54 This is possible, according to Freud, only by projection.

55 It could be debated if Freud has believed a certain type of family as a "universal" archetype or as a cultural contingency. Freud's account of origins of religion, as depicted in Totem and Taboo and in other works, seems to suggest that the father of psychoanalysis was closer to the first option.

56 Ibid., 108.
} 
— is given by the ontogenetic development of an individual, so secondary identification, the horizontal one, is ontogenetically determined and it is a direct consequence of the primary one.

In order to clarify this point, we need to see that, according to Freud, the child does not just want to be like the father, he wants to be loved by him. But a child would find out quite soon in his life that his father does not only love him, but also other people (especially siblings). In this situation, children will learn that in order to be loved by their father they have to show affection for all the other people his father loves. Trivially speaking, a father would never approve of his son's aggressive behaviour towards his siblings. Such behaviours, in fact, would risk turning away a father's love. Secondary identification, identification among individuals in a mass, comes from these well-known familiar dynamics, and then it is possible by virtue of vertical identification.

In Freud's words an individual wants to be like his father, or the substitute of his father, because he acknowledges a model in him..$^{57}$ But a model, to be considered as such, cannot correspond to the same Ego of the individual, rather it must be an ideal of Ego, something located on a different level in respect to the Ego. This is the reason why Freud defines a mass in these terms:

A primary group of this kind is a number of individuals who have put one and the same object in the place of their ego ideal and have consequently identified themselves with one another in their ego. ${ }^{58}$

The leader is the external object that individuals have put in the place of their ideal Ego. $\mathrm{He}$ is in fact a substitute of many objects of primary identification. This is why the leader keeps together a mass. We note that this explanation seems to successfully rule out contagion and suggestibility.

Now we have to examine how Freud explains a leader's efficacy. Freud criticized the notion of prestige, but he is not very clear in the positive characterization of a leader. It seems that the sole essential characteristic for a "Freudian" leader is to be a stranger to the mass. If a leader were part of the mass, the vertical identification would not be possible, and consequently there would not be any horizontal identification. Panic in fact is described by Freud as the moment in which, in the absence of a leader, the mass starts to break up and everybody thinks for themselves. ${ }^{59}$

We still hold a crucial question to answer. Why a particular person is chosen as leader, that is as the only substitute of many different fathers? If we consider other Freudian texts, in particular Moses and Monotheism, we can say something more on this issue. It is hardly objectionable that Freud is significantly inclined to attribute extraordinary capacities to the leader. ${ }^{60}$ Of course mass members projections do play a crucial role in elevating the leader. But it seems that a single person is chosen as leader by virtue of his extraordinary characteristic or capacities. The leader seems to possess certain capacities objectively, ${ }^{61}$ through which he can play an active role in mass-leader dynamics.

\footnotetext{
${ }^{57}$ Ibid., 105.

58 Ibid., 116.

${ }^{59}$ Ibid., 95-97. This is a crisis, according with its second meaning we have presented.

${ }^{60}$ Sigmund Freud, Civilization and its Discontents, in The standard Edition of the Complete Psychological Works of Sigmund Freud. Vol. XXI (1927-1931), ed. J. Strachey (London: The Hogart Press, 1961), 141; S. Freud, 'Civilized' Sexual Morality and Modern Nervous Illness, in The Standard Edition of the Complete Psychological Works of Sigmund Freud. Vol. IX (1906-1908), ed. J. Strachey (London: The Hogart Press, 1959), 197; S. Freud, Moses and Monotheism, in The Standard Edition of the Complete Psychological Works of Sigmund Freud. Vol. XXIII (1937-1939), ed. J. Strachey (London: The Hogart Press, 1964), 28, 31, 37.

61 That is independently in regards to the mass.
} 
Before starting the next section, we would like to underline and make explicit one last point. As we saw Freud believes that primary identification with the father is ambivalent. An individual feels towards the father both love and hate. These two sentiments for psychoanalysis can naturally coexist, and this is a relevant fact for the explanation of mass behaviour. Depending on the prevalence of love or hate in the individuals composing a mass, we will have a substitute of the father who will be the object of love or the object of hate. It is important to note that in both cases the leader (or we could say the victim, in case the hate prevails) gives cohesion to a mass, aligning and converging on himself impulses that were already present in the members of the mass.

\section{Girard: the Leader and the Sacred}

The three authors considered so far seem to agree on the idea that the leader, in order to be considered as such, needs to be neatly distinguished from every other members of the mass he shepherds. Leader's distinctive properties are conceived as objective, for they are not just the result of what the mass thinks of him. Due to these special qualities the leader plays an active role in the process that brings to the formation of a mass. His social efficacy is objective, not epiphenomenal. However, each of the three authors fails at making explicit what these special qualities really are, and how these hypothetical features could hold such a predominant power in directing masses for long periods of time.

In this regard, René Girard's notion of mimesis may shed light on these issues and other problems explored so far. As Girard's studies have argued, mimesis does not need anything endowed with an objective attractive. In Violence and the Sacred the anthropologist explores those social behaviors and beliefs that do not seem to be grounded on an objective reality to support their existence. Girard sees that in a context of crisis it is not important the object or the objective attribute of something or somebody: a crisis may be economic, anyway, the economy is not the subject of crowd's attention. It may seem counterintuitive, but in Violence and the Sacred we read:

We must take care not to view the tragic conflict in terms of its immediate goals, even when they are objects of such consequence as a throne or a queen. $[\ldots]$ In the traditional view the object comes first, followed by human desires that converge independently on this object. Last of all comes violence, a fortuitous consequence of the convergence. As the sacrificial conflict increases in intensity, so too does the violence. It is no longer the intrinsic value of the object that inspires the struggle; rather, it is the violence itself that bestows value on the objects, which are only pretexts for a conflict. ${ }^{62}$

The value of an object or an individual is seen by Girard as merely relational. In other words, even when some social values appear as objective, they are utterly arbitrary instead. Through Girard's point of view, one might claim that a leader does not actually play any active role and that a mass does not really hold any decisional power. Individuals believe in what their own models/rivals believe: the conviction of their own models/rivals is sufficient proof of objective values and qualities. As Girard observes:

The slightest hint, the most groundless accusation, can circulate with vertiginous speed and is transformed into irrefutable proof. The corporate sense of conviction snowballs, each member taking confidence from his

\footnotetext{
${ }^{62}$ René Girard, Violence and the Sacred (London/New York: Continuum, 2005), 153.
} 
neighbor by a rapid process of mimesis. The firm conviction of the group is based on no other evidence than the unshakable unanimity of its own illogic. ${ }^{63}$

This explains the power of the illusion with which a group of followers is imbued, the feeling that runs through them when they believe to be withstanding a revelation and their willingness to comply with the truth. Weber tackles the issue but fails in framing it through the lens of the sociological studies. Girard's theory instead can be proficiently applied to explain how a charismatic individual can rise as a crisis solver. It clarifies, in fact, why a mass selects, without really choosing, a leader, and by doing so it suddenly renders this individual exceptional and neatly distinguished from the rest. What sets the events in motion is individuals' willingness to comply with their models' ones: this is the true meaning of mimetic contagion. The charismatic power is not bestowed upon an individual by divine grace, but rather is given by the shared approval of a crowd. It is the mass that takes on the presumed divine authority to choose an exceptional figure without even realizing to be doing so. The mass is the "divine." As the anthropologist points out, these dynamics work well precisely thanks to a méconnaissance.

The follower's conviction about heroic charisma can be therefore considered a myth. Myths talk about exceptional individuals, like Oedipus, who are sometimes heroes and sometimes monsters, sometimes saviors and sometimes culprits. Freud shows that the oscillation is really caused by contradictory feelings of the mass and Girard shows that the real engine is mimesis. In Job, the Victim of His People the anthropologist writes:

The role of double mimesis in the history of Job enables us to understand why human communities are driven to follow certain individuals blindly and then to turn against them just as blindly.

Social science has tried to define a typical leader by using such notions as charisma. Here we should note the use of the language of the sacred. Charisma comes from Charis, meaning grace, who was a goddess. Charisma is defined as if it were yet another characteristic of the leader's personality, like the color of his hair or the mould of his chin. If that were true the leader's charisma would not be so easily transformed, as it is, into the anti-charisma or counter-charisma of the scapegoat. ${ }^{64}$

This reflection on the term "charisma" is also valid for Le Bon's "prestige". As Silvio Morigi emphasizes, the French anthropologist "draws the attention on the etymon of 'prestige', which reverses its usual meaning." 65 Girard in Things Hidden Since the Foundation of the World, criticizing the alleged prestige of the model, reminds us that praestigia is Latin for "spells and phantasmagoria." 66

Now one can legitimately wonder why the same mechanism causes the appointment of a scapegoat and the acknowledgment of a charismatic leader. A figure once bestowed with leadership might be turned suddenly into a scapegoat by the same crowd that had once chosen him as its shepherd. When this happens, a leader is no longer acknowledged as a charismatic figure, in that a scapegoat can never be a model and can never represent the pinnacle of a vertical identification: as a matter of fact he becomes a demonized victim, a monster. As Girard writes in Job, the Victim of His People, the scapegoat is an anti-charismatic figure. It is

\footnotetext{
${ }^{63}$ Ibid., 83-4.

${ }^{64}$ René Girard, Job, the Victim of His People (Stanford, California: Stanford University Press, 1987), 69.

${ }^{65}$ S. Morigi, "Sociologia dei sociologi" e "sociologia romanzesca" del primo Girard (Cosmopolis: rivista di filosofia e teoria politica), https://www.cosmopolisonline.it/articolo.php?numero=XIV122017\&id=14 (accessed March 30, 2019). Our translation.

${ }^{66}$ René Girard, Things Hidden Since the Foundation of the World (London: A\&C Black, 2003), 295.
} 
not clear why in a context of social crisis, which causes undifferentiation and collective violence, we may not observe the dynamic of all against one, but the dynamic of all around one, the leader.

Girard does not focus on the desire of a model, an exemplary individual, but just on the need to release the violence against one. Nevertheless, we can infer from this unconscious need the equally unconscious desire of a leader: his role, in fact, is precisely to provide a culprit, someone where to direct a revamped wave of violence and hatred. The mimetic contagious here results fundamental in uniting the crowd against just one victim, spreading quickly negative feelings and intention towards the same recipient (Weber's alleged "exemplary" individual, Le Bon's alleged "prestigious" model, Freud's alleged "father"). It is true also the opposite: if the mass selects just one culprit, it is simpler to acknowledge in his rival the model for all. Girard describes the transition from many rivalries to just one; we can add the implicit transition from many models to just one, the supreme model, the sacred one.

Naturally it is not necessary, as a judgment of guilt may easily spread even without just one recipient: everyone could in fact be influenced by different models who indicate the same culprit. As a matter of fact we can observe a mass without a charismatic individual. We must not forget that no one "decides" to be a model, even less so the supreme one, the leader, which is actually the most passive individual of all, completely at the mercy of the mimetic oscillation. A leader has a good chance of arising, because he clearly facilitates the unanimity. He is useful if he is the model who keeps the followers together against the enemy. Now the efficacy of the alleged heroism is clear: the "heroism," which opposes the "monster," usually the pre-existing authority, is a revolutionary force that unites the mass.

Myths confirm this hypothesis. The hero is the one who saves the community from a monster. The real role played by leaders in the social process that brings to a mass is understandable. Oedipus is the hero when he saves Thebes from the sphinx, and he is a culprit when Tiresias reveals it. Girard has discovered that the Thebans myths reveal how the scapegoat mechanism solves a social crisis, but he has not pointed out that they tell also how the same mechanism constitutes and destroys a charismatic authority. The story of sphinx's death is the same as Oedipus' accent to Thebes' throne, whereas the story of Oedipus' condemnation is the same as Tiresias' consecration. The end of a crisis coincides always with both the defeat of the "monster" and the appearance of a "charismatic" authority at the same time. As we said, followers and their mythological narration depict the leader as the protagonist and Weber, Le Bon and Freud's mistake is to accept this narrative.

Truth is, the only real protagonist is mimesis, however. The proof is that the future leader, before the "revelation," is a potential scapegoat just as his rival. The possibility of being a scapegoat is present from the beginning, not only at the end. Girard, commenting on Sophocles' Oedipus the King, acutely observes:

Oedipus and Tiresias each attempt to place the blame for the city's plight on the other; the accusations of patricide and incest are only especially striking contributions to a conventional exchange of incivilities. At this stage of the debate there is no reason to assume that either party is more guilty of any crime than the other. Both sides seem equally matched; neither seems able to gain the upper hand. ${ }^{67}$

Only mimesis will "decide" their fate. In fact, in accordance with Girard's hypothesis on the origin of sacred, the same individual appeared initially both as the hero and as monster at the same time. It is only at a later stage that the community began to tell the difference between a charismatic figure and a culprit, a leader and an enemy.

${ }^{67}$ René Girard, Violence and the Sacred (London - New York: Continuum, 2005), 77. 
Now, getting back to the French Revolution, we find only confirmations to this argument. Robespierre and Napoleon were appointed as leaders by an admiring mass that saw them as magnificent wardens against either an oppressive power or foreign threats. However, when they stopped being the "defenders of the people," they quickly slipped from their position of leadership and were suddenly appointed as the real culprits for all the country's problems. Naturally we do not argue that the French leaders' actions were irrelevant, but none of them were the actual foundation of their leadership, because it was mimesis that made them decisive, attracting first feelings of awe and approval and then of hate and resentment.

Robespierre neither "set up the principle of Virtue as supreme" nor founded a "Reign of Terror": it was clearly the mimetic mechanism which initially spread a new "ideal of Virtue" and later caused a collective violence backlash, the "Reign of Terror." Initially he opposed the declaration of war against Austria and Prussia, then he became the great defender of France against their threat. ${ }^{68}$ After the military victory, he was seen as the tyrant, the real culprit and ironically he was killed in the same way as he had "heroically freed" France from King Louis XVI's tyranny: the mimetic oscillation that decided his fate emerges clearly from Robespierre's biography.

Napoleon's fate was decided by this oscillation as well. We have no doubt that he was really a great military commander, but this objective quality did not constitute his charismatic authority. As a matter of fact, he was not regarded as a conqueror, but after the end of the modern age he became an emperor, sailing proficiently the social restoration set in motion by the storming of the Bastille. In Deceit, Desire and the Novel Girard gives credits to Tolstoj's representation:

Tolstoj's Napoleon offers an example of a great self-control headed for slavery. Like all bourgeois, Napoleon is a parvenu who owes his success to the ascetic instinct of internal mediation. Like all bourgeois, he confuses this ascetic instinct with the categorical imperative of an absolutely disinterested ethic. But in the midst of his triumph Napoleon discovers that nothing in him has changed and this discovery plunges him into despair. He wants to track down in another's gaze a reflection of that divinity which still eludes him. He wants to be emperor by "divine right", to proclaim his will urbi et orbi, to demand obedience from the entire world. ${ }^{69}$

Napoleon was revered like a god and hated like a demon. In this case the oscillation was extreme: French people repeatedly glorified him for his success and condemned him for his bybris, changing their minds with a speed than only mimesis can explain. In Battling to the End the anthropologist studies German elite's hate and, at the same time, admiration, focusing particularly on Carl von Clausewitz and his work $O n W a r$.

Clausewitz is incredibly obsessed by Napoleon, who functions precisely as what I call a model-obstacle: a model that is attractive and repulsive at the same time, and is the source of the mental pathologies that Dostoevskij has described so well. ${ }^{70}$

Napoleon's story, his rise and fall, is incredibly similar to a myth, told across the whole of Europe. In contrast to the dictators of the $20^{\text {th }}$ century, he is still a myth in many history books. But now we can clarify the truth.

\footnotetext{
68 P.R. Hanson, Contesting the French Revolution (West Sussex: Wiley-Blackwell, 2009), 122-123.

${ }^{69}$ René Girard, Deceit, Desire and the Novel (Baltimore, Maryland: The Johns Hopkins Press, 1965), 165-6.

${ }^{70}$ René Girard, Battling to the End (East Lansing, Michigan: Michigan State University Press, 2010), 11.
} 


\section{Conclusion}

We can now appreciate the peculiarity of Girard's theoretical framework which overturns Weber, Le Bon, and Freud's accounts, by claiming that the leader does not play any active role and none of his objective qualities have a significant causal power ${ }^{71}$.

We have worked out this table below (see Fig. 1) in order to show graphically the different positions presented along this paper and to to advance a possible summary.

Our table shows that Freud was closer to Girard's position regarding the ambivalent role of the leader. Freud focused on masses as a system, while Le Bon, perhaps due to his political prejudices against crowds, looked at the mass as a fierce antagonist of external social institutions. This allowed Freud to see better that the leader (intended both as proper leader and as "negative leader," that is what Girard would call a scapegoat) is always the solver of a crisis. Freud has also anticipated Girard in what concerns one crucial point: ambivalence is not due to the leader himself, but to the emotions of the people that gather around him instead.

One further consideration favors Girard's account as compared to the Freudian one. Within Girard's theoretical framework the gender, as any objective quality, is irrelevant to define the leadership. On the other side we should not forget that according to Freud the leader is the substitute of a father figure. Therefore, Girard's conceptual tools allow us not to give priority to any male figure at the expense of female leaders.

\begin{tabular}{|l|c|c|c|c|}
\hline $\begin{array}{l}\text { Role of the leader } \\
\text { Active/Passive/Both }\end{array}$ & Beber & Le Bon & Freud & Girard \\
\hline $\begin{array}{l}\text { Leader's objective } \\
\underline{\text { features }}\end{array}$ & Yes & Yoth & Both & Passive \\
\hline $\begin{array}{l}\text { Yes/No } \\
\text { exasperation }\end{array}$ & Can be both & $\begin{array}{c}\text { Can be } \\
\text { both } \\
\text { Bolver/Exasperation/ }\end{array}$ & Solver & No \\
\hline $\begin{array}{l}\text { Account for } \\
\text { ambivalence }\end{array}$ & $\begin{array}{c}\text { It depends on } \\
\text { the leader }\end{array}$ & $\begin{array}{c}\text { It depends } \\
\text { on the } \\
\text { leader }\end{array}$ & $\begin{array}{c}\text { Individuals } \\
\text { emotions are } \\
\text { ambivalent }\end{array}$ & $\begin{array}{c}\text { Individuals } \\
\text { emotions are } \\
\text { ambivalent }\end{array}$ \\
\hline
\end{tabular}

Fig. 1. Summary of the Four Theoretical Frameworks

Of course, Girard's theoretical framework has to face some challenges. One possible objection could be: why individuals in a mass imitate each other? It is a relevant issue within Girardian studies to establish where mimesis comes from. For obvious reasons we cannot go into details and we just mention one interesting hypothesis recently given by the philosopher Gianfranco Mormino, ${ }^{72}$ who has argued that mimesis is a derivative form of self-imitation. Anyway, Girard's theory is relatively young and must be explored in different directions. In

\footnotetext{
${ }^{71}$ A particular trait - something that could become a victimary sign - can be (but it does not have to be) in some sense "objective," but it absolutely cannot explain, taken as a mere individual's property, any mass dynamics.

${ }^{72}$ Gianfranco Mormino, Per una Teoria dell'Imitazione, (Milano: Raffaello Cortina Editore, 2016).
} 
this regard our paper could represent a theoretical contribute for the articulation of "the broad lines of [Girard's] mimetic theory in its relation to history." 73

\section{References}

Borch-Jacobsen, Mikkel. The Freudian Subject. Edited by C. Porter. Stanford: Stanford University Press, 1988.

Freud, Sigmund. Civilization and its Discontents, in The standard Edition of the Complete Psychological Works of Sigmund Freud. Vol. XXI (1927-1931). Edited by J. Strachey. London: The Hogart Press, 1961.

. 'Civilized' Sexual Morality and Modern Nervous Illness, in The Standard Edition of the Complete Psychological Works of Sigmund Freud. Vol. IX (1906-1908). Edited by J. Strachey. London: The Hogart Press, 1959.

. Group Psychology and the Analysis of the Ego, in The Standard Edition of the Complete Psychological Works of Sigmund Freud. Vol. XVIII (1920-1922). Edited by J. Strachey. London: The Hogart Press, 1957.

Moses and Monotheism, in The Standard Edition of the Complete Psychological Works of Sigmund Frend. Vol. XXIII (1937-1939). Edited by J. Strachey. London: The Hogart Press, 1964.

Girard, René. Battling to the End. East Lansing, Michigan: Michigan State University Press, 2010

. Deceit, Desire and the Novel. Baltimore, Maryland: The Johns Hopkins Press, 1965. . Job, the Victim of His People. Stanford, California: Stanford University Press, 1987. . Things Hidden Since the Foundation of the World. London: A\&C Black, 2003. Violence and the Sacred. London - New York: Continuum, 2005.

Hanson, Paul R. Contesting the French Revolution. West Sussex: Wiley-Blackwell, 2009.

Hegel, Georg W.F. The Philosophy of History. Kitchener, Ontario: Batoche Books, 2001.

Le Bon, Gustave. The Crowd: a Study of the Popular Mind. New York: Cosimo Classics, 2006.

McPhee, Peter. Robespierre and Violence, in Experiencing the French Revolution. Ed. D. Andress. Oxford: Voltaire Foundation, 2013.

Morigi, Silvio. "Sociologia dei Sociologi" e "Sociologia Romanzesca" del primo Girard. Ed. Cosmopolis: rivista di filosofia e teoria politica.

https://www.cosmopolisonline.it/articolo.php?numero=XIV122017\&id=14 (Accessed March 30, 2019).

Mormino, Gianfranco. Per una Teoria dell'Imitazione. Milano: Raffaello Cortina Editore, 2016.

Weber, Karl E. M. Economy and Society: an Outline of Interpretative Sociology. Los Angeles, California: University of California Press, 2001.

\footnotetext{
${ }^{73}$ René Girard, Battling to the End (East Lansing, Michigan: Michigan State University Press, 2010), 1.
} 